\title{
Preparation and Characterization of 1,2,3,4- Butane four Carboxylate Transition Metal Complexes
}

\author{
Kanglong Zhang, Xiaojin Qi \\ China University of Mining and Technology Yinchuan College
}

\begin{abstract}
Na}_{4} \mathrm{C}_{8} \mathrm{H}_{6} \mathrm{O}_{8}\right)$ is mainly used to prepare photosensitive materials, medical polymer materials and functional polymer membrane materials.As a permanent finishing agent, 1,2,3,4butane four carboxylic acid plays an irreplaceable role.In this paper, the preparation of metal complexes by the reaction of 1,2,3,4-butane tetracarboxylic acid tetrasodium salt $\left(\mathrm{Na}_{4} \mathrm{C}_{8} \mathrm{H}_{6} \mathrm{O}_{8}\right)$ with transition metals is described. The composition and structure of the prepared metal complexes were characterized by infrared spectroscopy, thermogravimetric analysis and elemental analysis. At the same time, through the analysis of thermogravimetric curves, the order of thermal stability of metal complexes is (from large to small): $\mathrm{Co}_{2} \mathrm{C}_{8} \mathrm{H}_{6} \mathrm{O}_{8} \cdot 2 \mathrm{H}_{2} \mathrm{O}>$ $\mathrm{Cd}_{2} \mathrm{C}_{8} \mathrm{H}_{6} \mathrm{O}_{8} \cdot 2 \mathrm{H}_{2} \mathrm{O}>\mathrm{Mn}_{2} \mathrm{C}_{8} \mathrm{H}_{6} \mathrm{O}_{8} \cdot 2 \mathrm{H}_{2} \mathrm{O}>\mathrm{Ni}_{2} \mathrm{C}_{8} \mathrm{H}_{6} \mathrm{O}_{8} \cdot 2 \mathrm{H}_{2} \mathrm{O}>\mathrm{Zn}_{2} \mathrm{C}_{8} \mathrm{H}_{6} \mathrm{O}_{8} \cdot 2 \mathrm{H}_{2} \mathrm{O}>\mathrm{Zn}_{2} \mathrm{C}_{8} \mathrm{H}_{6} \mathrm{O}_{8} \cdot 2 \mathrm{H}_{2} \mathrm{O}>$ $\mathrm{Cu}_{2} \mathrm{C}_{8} \mathrm{H}_{6} \mathrm{O}_{8} \cdot 2 \mathrm{H}_{2} \mathrm{O}$.
\end{abstract}

Keywords: Transition metal complexes; thermogravimetric analysis; 1,2,3,4- butane four carboxylic acid; IR spectra

1,2,3,4-butane tetracarboxylic acid $\left(\mathrm{Na}_{4} \mathrm{C}_{8} \mathrm{H}_{6} \mathrm{O}_{8}\right)$ is mainly used to prepare photosensitive materials, medical polymer materials and functional polymer membrane materials. As a permanent calendering agent, 1,2,3,4-butane tetracarboxylic acid has no formaldehyde in itself. Cotton and silk articles treated by it can obtain wrinkle resistance, solid shape and ironing-free properties. At present, the synthesis methods of 1,2,3,4-butane tetracarboxylic acid have been reported in China, but the literature on transition metal complexes of 1,2,3,4-butane tetracarboxylic acid is less. Therefore, this paper will further study and prepare metal complexes [1] $\mathrm{Co}, \mathrm{Cu}, \mathrm{Ni}$, $\mathrm{Mn}, \mathrm{Zn}, \mathrm{Cd}$ and so on.

\section{Experiment}

\subsection{Major reagents}

(1) 1,2,3,4- butane four carboxylic acid $\left(\mathrm{Na}_{4} \mathrm{C}_{8} \mathrm{H}_{6} \mathrm{O}_{8}\right)$.

(2) Two times distilled water.

(3) $\mathrm{NaOH}, \mathrm{Cd}\left(\mathrm{NO}_{3}\right)_{2} \cdot 4 \mathrm{H}_{2} \mathrm{O}$ (the transition metal chlorides are all analytically pure).

\subsection{Preparation of transition metal complexes of 1,2,3,4- butane four carboxylic acid with $\mathrm{Cu}$ as an example}

In the preparation of copper, the first step is to weigh the amount of $\mathrm{H}_{4} \mathrm{C}_{8} \mathrm{H}_{6} \mathrm{O}_{8}$ molten water, add $30 \% \mathrm{NaOH}$ water solution while stirring, cool it, adjust the acidity and alkalinity to PH5-6, and concentrate the reaction solution. After cooling, the crystallization of 1,2,3,4- butane four carboxylic acid will be obtained. The white powder of $\mathrm{Na}_{4} \mathrm{C}_{8} \mathrm{H}_{6} \mathrm{O}_{8}$ was obtained by drying it at $90 \mathrm{C}$ for 12 hours, and then it was put into a dryer for use. At this time, the quantitative $\mathrm{Na}_{4} \mathrm{C}_{8} \mathrm{H}_{6} \mathrm{O}_{8}$ is weighed and dissolved in water After stirring and adding $\mathrm{Cu} \mathrm{C}_{12}$ to the aqueous solution, it should be noted that the mass ratio of $\mathrm{CuC} \mathrm{C}_{12}$ to $\mathrm{Na}_{4} \mathrm{C}_{8} \mathrm{H}_{6} \mathrm{O}_{8}$ is 2. It can be observed that a large number of blue precipitates are precipitated in the reaction solution, which is heated to $60-70{ }^{\circ} \mathrm{C}$ and stirred for 1 hour, and then cooled and filtered. Wash the precipitates with hot water for 3 times and remove the $\mathrm{F}$ in the precipitates. The blue precipitate $\mathrm{Cu}_{2} \mathrm{C}_{8} \mathrm{H}_{6} \mathrm{O}_{8} \cdot n \mathrm{H}_{2} \mathrm{O}$ was then dried at $75{ }^{\circ} \mathrm{C}$ for 12 hour. The preparation of other metal complexes is basically the same as that of $\mathrm{Cu}$ complexes, but $\mathrm{Cd}$ complexes are made by $\mathrm{Cd}\left(\mathrm{NO}_{3}\right)_{2} \cdot 4 \mathrm{H}_{2} \mathrm{O}$ and $\mathrm{Na}_{4} \mathrm{C}_{8} \mathrm{H}_{6} \mathrm{O}_{8}$ [2].

\subsection{Using thermogravimetric analysis}

In the analysis phase, the thermogravimetric analyzer (Pyris 1 TGA) produced by Perkin-Elmer is used. Use $\mathrm{M}_{2} \mathrm{C}_{8} \mathrm{H}_{6} \mathrm{O}_{8} \cdot n \mathrm{H}_{2} \mathrm{O}, \quad \mathrm{Co}_{2} \mathrm{C}_{8} \mathrm{H}_{6} \mathrm{O}_{8} \cdot n \mathrm{H}_{2} \mathrm{O}, \quad \mathrm{Ni}_{2} \mathrm{C}_{8} \mathrm{H}_{6} \mathrm{O}_{8} \cdot n \mathrm{H}_{2} \mathrm{O}$, $\mathrm{Cu}_{2} \mathrm{C}_{8} \mathrm{H}_{6} \mathrm{O}_{8} \cdot n \mathrm{H}_{2} \mathrm{O}, \quad \mathrm{Zn}_{2} \mathrm{C}_{8} \mathrm{H}_{6} \mathrm{O}_{8} \cdot n \mathrm{H}_{2} \mathrm{O}, \mathrm{Cd}_{2} \mathrm{C}_{8} \mathrm{H}_{6} \mathrm{O}_{8} \cdot n \mathrm{H}_{2} \mathrm{O}$ to analyze and analyze the data. It can be observed that when the heating rate reaches $20^{\circ} \mathrm{C}$ per minute and the number of samples is $6 \mathrm{mg}$, when the temperature is between $30^{\circ} \mathrm{C}$ and 850 , the flow rate of dry air is $20 \mathrm{ml}$ per minute as the atmosphere. 


\subsection{Elemental analysis by infrared spectroscopy}

In element analysis, the Fourier transform infrared spectrometer (Spectrum GX) produced by Perkin-Elmer Company and the DITGS detector are still used. After preparing the relevant testing instruments, we use $\mathrm{KBr}$ pressing method to test. At the same time, he found that the resolution of the spectrum was $4 \mathrm{~cm}^{-1}$, and the range of this test was between $4000 \mathrm{~cm}^{-1}$ and $400 \mathrm{~cm}^{-1}$. The cumulative number of signals in the test scan is 64 times, the gain is 1 , and the speed of OPD is $0.2 \mathrm{~cm}$ per second [3].

\section{Experimental result}

\subsection{Determine the composition of 1,2,3,4- butane four carboxylic acid over metal complexes}

Thermogravimetric analysis and elemental analysis can be used to verify the molecular formula of $\mathrm{Mn}_{2} \mathrm{C}_{8} \mathrm{H}_{6} \mathrm{O}_{8}$. The acquisition of $\mathrm{Mn}_{2} \mathrm{C}_{8} \mathrm{H}_{6} \mathrm{O}_{8}$ can be achieved by reacting $\mathrm{M}^{2+}$ with $\left(\mathrm{C}_{8} \mathrm{H}_{6} \mathrm{O}_{8}\right)$. At the same time, according to the derivative thermogravimetric curves and thermogravimetric curves (as shown in Fig. 1 and Fig. 2), it is determined that the molecular formula of the final product is $\mathrm{Mn}_{2} \mathrm{C}_{8} \mathrm{H}_{6} \mathrm{O}_{8} \cdot n \mathrm{H}_{2} \mathrm{O}$.

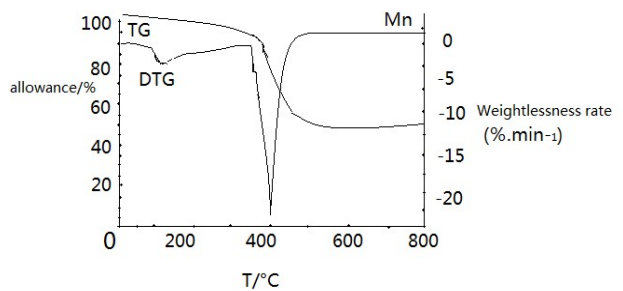

Figure 1. Derivative thermogravimetric curves.

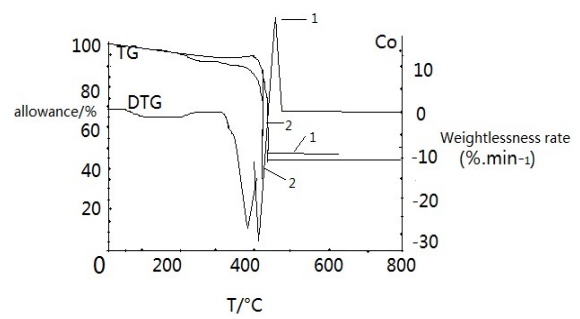

Figure 2. Thermogravimetric curves

(1) The sample quality was $6302 \mathrm{mg}$, the experimental temperature range was $30^{\circ} \mathrm{C}$ to $850^{\circ} \mathrm{C}$.

(2) The sample quality was $2028 \mathrm{mg}$, the experimental temperature range was $30^{\circ} \mathrm{C}$ to $650^{\circ} \mathrm{C}$

Through the observation of the icon, it can be found that the weight loss rate of crystalline water is when the thermogravimetric curve rises to the first stage. At the same time, the value of $\mathrm{N}$ can be further obtained based on this data. Under general experimental conditions, the products of thermal decomposition of the transition metal complexes are $\mathrm{Cdo}, \mathrm{CuO}, \mathrm{ZnO}, \mathrm{NiO}, \mathrm{Co}_{3} \mathrm{O}_{4}, \mathrm{Mn}_{2} \mathrm{O}_{3}$ and so on, in the range of temperature between $30 \mathrm{C}$ and 850
C. At the same time, by analyzing the thermogravimetric data in the experiment (as shown in Table 1), it can be found that the mass fraction values of various complexes after thermal decomposition are basically consistent with the theoretical values, which further illustrates the correctness of the original formulation. Therefore, we can get the theoretical values of $\mathrm{H} \%$ and $\mathrm{C} \%$ according to the formulated chemical formula. After calculating the values we can put the corresponding data into Table 2. Through the analysis of Table 2, we can conclude that the composition of the two elements $(\mathrm{C}$ and $\mathrm{H})$ is basically the same as the formulated data. From this, we can see that the chemical formula of the complex is $\mathrm{M}_{2} \mathrm{C}_{8} \mathrm{H}_{6} \mathrm{O}_{8} \cdot n \mathrm{H}_{2} \mathrm{O}$, and the analysis results can thus be determined. Molecular formula for over metal complexes.

Table 1. Thermogravimetric data of complex in dynamic air atmosphere

\begin{tabular}{|c|c|c|c|c|}
\hline \multirow{2}{*}{ Complex } & \multicolumn{2}{|c|}{ Crystallized water } & \multirow{2}{*}{$\begin{array}{c}\text { Residual mass fraction/\% } \\
\begin{array}{c}\text { Measured value } \\
\text { (calculated value) }\end{array}\end{array}$} & \multirow{2}{*}{$\begin{array}{c}\text { Thermal } \\
\text { decomposition of } \\
\text { finaloxidation } \\
\text { products }\end{array}$} \\
\hline & $\begin{array}{l}\text { Weightlessness } \\
\text { rate } \% \%\end{array}$ & $n$ & & \\
\hline $\mathrm{Mn}_{2} \mathrm{C}_{8} \mathrm{H}_{6} \mathrm{O}_{8} \cdot n \mathrm{H}_{2} \mathrm{O}$ & 9.13 & 2 & $4238(4200)$ & $\mathrm{Mn}_{2} \mathrm{O}_{3}$ \\
\hline $\mathrm{Co}_{2} \mathrm{C}_{8} \mathrm{H}_{6} \mathrm{O}_{8} \cdot n \mathrm{H}_{2} \mathrm{O}$ & 9. 20 & 2 & $4225(4180)$ & $\mathrm{Co}_{3} \mathrm{O}_{4}$ \\
\hline $\mathrm{Ni}_{2} \mathrm{C}_{8} \mathrm{H}_{6} \mathrm{O}_{8} \cdot n \mathrm{H}_{2} \mathrm{O}$ & 16.84 & 4 & $3532(3560)$ & $\mathrm{NiO}$ \\
\hline $\mathrm{Cu}_{2} \mathrm{C}_{8} \mathrm{H}_{6} \mathrm{O}_{8} \cdot n \mathrm{H}_{2} \mathrm{O}$ & 5. 02 & 1 & $4260(4240)$ & Cuo \\
\hline $\mathrm{Zn}_{2} \mathrm{C}_{8} \mathrm{H}_{6} \mathrm{O}_{8} \cdot n \mathrm{H}_{2} \mathrm{O}$ & 9.26 & 2 & $4158(4101)$ & Zno \\
\hline $\mathrm{Cd}_{2} \mathrm{C}_{8} \mathrm{H}_{6} \mathrm{O}_{8} \cdot n \mathrm{H}_{2} \mathrm{O}$ & 7. 67 & 2 & $5191(5230)$ & $\mathrm{CdO}$ \\
\hline
\end{tabular}

Table 2. $\mathrm{M}_{2} \mathrm{C}_{8} \mathrm{H}_{6} \mathrm{O}_{8} \cdot n \mathrm{H}_{2} \mathrm{O}$ elemental analysis data

\begin{tabular}{lccc}
\hline & & \multicolumn{2}{c}{$\begin{array}{c}\text { Elemental analysis, measured values (calculated } \\
\text { values) } \%\end{array}$} \\
\cline { 3 - 4 } Complex & Colour & $\mathrm{C}$ & $\mathrm{H}$ \\
\hline $\mathrm{Mn}_{2} \mathrm{C}_{8} \mathrm{H}_{6} \mathrm{O}_{8} \cdot 2 \mathrm{H}_{2} \mathrm{O}$ & White & $2524(2553)$ & $276(268)$ \\
$\mathrm{Co}_{2} \mathrm{C}_{8} \mathrm{H}_{6} \mathrm{O}_{8} \cdot 2 \mathrm{H}_{2} \mathrm{O}$ & Violet & $2469(2500)$ & $269(263)$ \\
$\mathrm{Ni}_{2} \mathrm{C}_{8} \mathrm{H}_{6} \mathrm{O}_{8} \cdot 4 \mathrm{H}_{2} \mathrm{O}$ & Yellowish green & $2257(2288)$ & $343(336)$ \\
$\mathrm{Cu}_{2} \mathrm{C}_{8} \mathrm{H}_{6} \mathrm{O}_{8} \cdot \mathrm{H}_{2} \mathrm{O}$ & Blue & $2520(2559)$ & $230(215)$ \\
$\mathrm{Zn}_{2} \mathrm{C}_{8} \mathrm{H}_{6} \mathrm{O}_{8} \cdot 2 \mathrm{H}_{2} \mathrm{O}$ & White & $2408(2417)$ & $262(254)$ \\
$\mathrm{Cd}_{2} \mathrm{C}_{8} \mathrm{H}_{6} \mathrm{O}_{8} \cdot 2 \mathrm{H}_{2} \mathrm{O}$ & White & $1921(1955)$ & $210(205)$ \\
\hline
\end{tabular}

\subsection{Data analysis using infrared spectroscopy}

Infrared spectra of 1,2,3,4-butane tetracarboxylic acid, 1,2,3,4-butane tetracarboxylic acid tetrasodium salt and their transition metal complexes were determined by infrared spectroscopy. The spectra of these three elements are shown in Table 2 (for transition metals, manganese is taken as an example, and the main characteristic peaks of A infrared spectra are shown in Table 3 ).

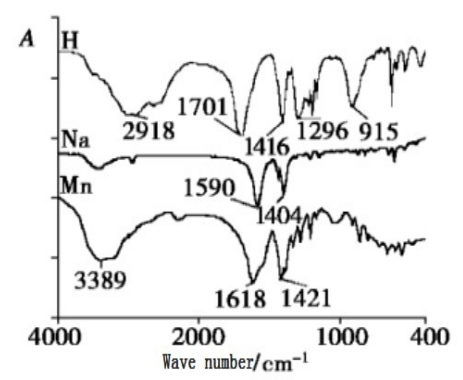

Figure 3. Infrared spectra comparison of 1,2,3,4- butane four carboxylic acid and four sodium salt and manganese complex. 
Table 3. $\mathrm{M}_{2} \mathrm{C}_{8} \mathrm{H}_{6} \mathrm{O}_{8} \cdot n \mathrm{H}_{2} \mathrm{O}$ main characteristic peaks of infrared spectra $\mathrm{cm}^{-1}$

\begin{tabular}{lcccc}
\hline \multicolumn{1}{c}{ Complex } & $v_{\mathrm{OH}}$ & $v_{\text {as }}(\mathrm{coo})$ & $v_{s}(\mathrm{coo})$ & $v_{\text {as }}-v_{s}$ \\
\hline $\mathrm{Na}_{4} \mathrm{C}_{8} \mathrm{H}_{6} \mathrm{O}_{8}$ & 3443 & 1590 & 1404 & 186 \\
$\mathrm{Mn}_{2} \mathrm{C}_{8} \mathrm{H}_{6} \mathrm{O}_{8} \cdot 2 \mathrm{H}_{2} \mathrm{O}$ & 3389 & 1618 & 1421 & 197 \\
$\mathrm{Co}_{2} \mathrm{C}_{8} \mathrm{H}_{6} \mathrm{O}_{8} \cdot 2 \mathrm{H}_{2} \mathrm{O}$ & 3390 & 1630 & 1419 & 211 \\
$\mathrm{Ni}_{2} \mathrm{C}_{8} \mathrm{H}_{6} \mathrm{O}_{8} \cdot 4 \mathrm{H}_{2} \mathrm{O}$ & 3394 & 1631 & 1420 & 211 \\
$\mathrm{Cu}_{2} \mathrm{C}_{8} \mathrm{H}_{6} \mathrm{O}_{8} \cdot \mathrm{H}_{2} \mathrm{O}$ & 3447 & 1638 & 1434,1416 & 204,222 \\
$\mathrm{Zn}_{2} \mathrm{C}_{8} \mathrm{H}_{6} \mathrm{O}_{8} \cdot 2 \mathrm{H}_{2} \mathrm{O}$ & 3379 & 1585 & 1423 & 162 \\
$\mathrm{Cd}_{2} \mathrm{C}_{8} \mathrm{H}_{6} \mathrm{O}_{8} \cdot 2 \mathrm{H}_{2} \mathrm{O}$ & 3400 & 1578,1541 & 1434,1413 & $<186$ \\
\hline
\end{tabular}

In the infrared spectra of 1,2,3,4-butane tetracarboxylic acid $\left(\mathrm{Na}_{4} \mathrm{C}_{8} \mathrm{H}_{6} \mathrm{O}_{8}\right)$, the $\mathrm{C}=\mathrm{O}$ bond strong absorption peaks of $-\mathrm{COOH}$ are at $1701 \mathrm{~cm}^{-1}$, and a pair of vibration coupling absorption peaks are at $1296 \mathrm{~cm}^{-1}$ and $1416 \mathrm{~cm}^{-1}$, respectively. At the same time, it can be further found that the out-of-plane angular variation of dimer carboxylic acid $\mathrm{OH}$ group caused wide peaks at $920 \mathrm{~cm}^{-1}$ due to vibration. However, in the infrared spectra of 1,2,3,4-butanetetracarboxylic acid $\left(\mathrm{Na}_{4} \mathrm{C}_{8} \mathrm{H}_{6} \mathrm{O}_{8}\right)$ and $M_{2} \mathrm{C}_{8} \mathrm{H}_{6} \mathrm{O}_{8} \cdot n \mathrm{H}_{2} \mathrm{O}$, the bond strength absorption peaks at $1701 \mathrm{~cm}^{-1}$ disappeared completely, and the broad peaks of the out-of-plane angular vibration of the dimer carboxylic acid $\mathrm{OH}$ group also disappeared. Based on these data, it can be further concluded that the metal ions in the experimental reactions are fully compatible with - $\mathrm{COOH}$, which leads to the disappearance of the $\mathrm{C}=\mathrm{O}$ bond strong absorption peak of - $\mathrm{COOH}$. This indicates that $\mathrm{COOH}$ does not exist in $\mathrm{M}_{2} \mathrm{C}_{8} \mathrm{H}_{6} \mathrm{O}_{8} \cdot n \mathrm{H}_{2} \mathrm{O}$, which is also consistent with the previous results of thermogravimetric analysis and elemental analysis [4]. You can see in Table 3 , there is a strong absorption peak at $3447 \mathrm{~cm}^{-1}$ to $3379 \mathrm{~cm}^{-1}$ wide, this broad absorption peak is due to changes in peak water of crystallization -OH stretching vibration caused by the certain. The characteristics of carboxylate bands by metal ions and the carboxyl oxygen coordination mode play a great role, with ion carboxylate in metal according to figure four (coordination) three ways of coordination of [5].

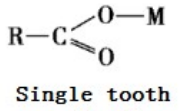

coordination
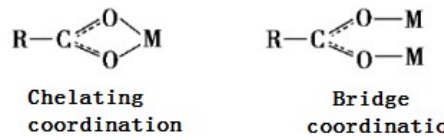

Figure 4. Coordination mode

It can be found that the size of $\Delta v \mathrm{coo}^{-}$is the same as that of ions and ionic compounds in the three coordination modes. For example, in the single-tooth coordination mode, the $\Delta \mathrm{vcoo}^{-}$of compound itself is much larger than that of free ions; in the chelating coordination mode, the $\Delta \mathrm{vcoo}^{-}$of compound is much smaller than that of ionic compounds in the chelating coordination mode [6]. At the same time, we can see the values of $v_{a s}\left(\mathrm{COO}^{-}\right)$and $v_{s}\left(\mathrm{COO}^{-}\right)$corresponding to $\mathrm{M}_{2} \mathrm{C}_{8} \mathrm{H}_{6} \mathrm{O}_{8} \cdot n \mathrm{H}_{2} \mathrm{O}$ in the experiment. In order to further facilitate the experimental analysis of coordination methods, the table lists the effective data related to 1,2,3,4-butane tetracarboxylic acid $\left(\mathrm{Na}_{4} \mathrm{C}_{8} \mathrm{H}_{6} \mathrm{O}_{8}\right)$, which serves as the basis for judging $\Delta v$. Taking $200 \mathrm{~cm}^{-1}$ as the critical point for judging, a single-tooth coordination is greater than this value, and a double-tooth coordination is less than this value. At the same time, we can use $\Delta v v^{-}$ of sodium carboxylate and $\Delta v \mathrm{coo}^{-}$of metal complex to judge and compare, so as to determine the form of coordination. According to the above experimental judgment basis, we can make further judgement. In the $\mathrm{Na}_{4} \mathrm{C}_{8} \mathrm{H}_{6} \mathrm{O}_{8}$ experiment of 1,2,3,4-butane tetracarboxylic acid, $\mathrm{Co}, \mathrm{Cu}$ and $\mathrm{Ni}$ metal complexes were used as single-tooth coordination, $\mathrm{Zn}$ and $\mathrm{Cd}$ metal complexes were used as chelating coordination, and $\mathrm{Mn}$ metal complexes were used as bridge coordination. However, in the actual experiment, which of the three coordination modes should be used, we should also analyze and prove [7].

\subsection{Data analysis using thermogravimetric analysis}

Through the experimental thermogravimetric analysis, it can be concluded that the complexes of transition metals in 1,2,3,4-butane tetracarboxylic acid $\left(\mathrm{Na}_{4} \mathrm{C}_{8} \mathrm{H}_{6} \mathrm{O}_{8}\right)$ experiment are different in the thermal decomposition process, which is caused by different transition metals. At the same time, we can further observe that there are two stages in the diagram of copper, $\mathrm{Cd}, \mathrm{Mn}, \mathrm{Ni}$ and $\mathrm{Zn}$ metal complexes: 1,2,3,4-butane tetracarboxylic acid $\left(\mathrm{Na}_{4} \mathrm{C}_{8} \mathrm{H}_{6} \mathrm{O}_{8}\right)$. During the weightlessness stage, Co metal complexes began to gain weight in the third stage. Through experiments, we can know that $\mathrm{CoO}$ is produced during the thermal decomposition of $\mathrm{CO}_{2} \mathrm{C}_{8} \mathrm{H}_{6} \mathrm{O}_{8} \cdot 2 \mathrm{H}_{2} \mathrm{O}$ at a specific temperature, and $\mathrm{CoO}$ is oxidized to form $\mathrm{Co}_{3} \mathrm{O}_{4}$. At the same time, we can further find that there is a big difference between the predicted and measured values of $\mathrm{CoO}$, which is due to the partial overlap between $\mathrm{CoO}$ and $\mathrm{Co}_{2} \mathrm{O}_{3}$ or $\mathrm{Co}_{3} \mathrm{O}_{4}$. From this we can speculate that in the whole thermal decomposition reaction, the changes experienced by the experimental substance are:

$$
\begin{aligned}
& \mathrm{Mn}_{2} \mathrm{C}_{8} \mathrm{H}_{6} \mathrm{O}_{8} \cdot 2 \mathrm{H}_{2} \mathrm{O} \rightarrow \mathrm{Mn}_{2} \mathrm{C}_{8} \mathrm{H}_{6} \mathrm{O}_{8} \rightarrow \mathrm{Mn}_{2} \mathrm{O}_{3} \\
& \mathrm{Co}_{2} \mathrm{C}_{8} \mathrm{H}_{6} \mathrm{O}_{8} \cdot 2 \mathrm{H}_{2} \mathrm{O} \rightarrow \mathrm{Co}_{2} \mathrm{C}_{8} \mathrm{H}_{6} \mathrm{O}_{8} \rightarrow \mathrm{CoO} \rightarrow \mathrm{Co}_{3} \mathrm{O}_{4} \\
& \mathrm{Ni}_{2} \mathrm{C}_{8} \mathrm{H}_{6} \mathrm{O}_{8} \cdot 2 \mathrm{H}_{2} \mathrm{O} \rightarrow \mathrm{Ni}_{2} \mathrm{C}_{8} \mathrm{H}_{6} \mathrm{O}_{8} \rightarrow \mathrm{NiO} \\
& \mathrm{Cu}_{2} \mathrm{C}_{8} \mathrm{H}_{6} \mathrm{O}_{8} \cdot 2 \mathrm{H}_{2} \mathrm{O} \rightarrow \mathrm{Cu}_{2} \mathrm{C}_{8} \mathrm{H}_{6} \mathrm{O}_{8} \rightarrow \mathrm{CuO} \\
& \mathrm{Zn}_{2} \mathrm{C}_{8} \mathrm{H}_{6} \mathrm{O}_{8} \cdot 2 \mathrm{H}_{2} \mathrm{O} \rightarrow \mathrm{Zn}_{2} \mathrm{C}_{8} \mathrm{H}_{6} \mathrm{O}_{8} \rightarrow \mathrm{ZnO} \\
& \mathrm{Cd}_{2} \mathrm{C}_{8} \mathrm{H}_{6} \mathrm{O}_{8} \cdot 2 \mathrm{H}_{2} \mathrm{O} \rightarrow \mathrm{Cd}_{2} \mathrm{C}_{8} \mathrm{H}_{6} \mathrm{O}_{8} \rightarrow \mathrm{CdO}
\end{aligned}
$$

At the same time, through the analysis of thermogravimetric curves, the order of thermal stability of metal complexes from large to small is obtained as follows: $\mathrm{Co}_{2} \mathrm{C}_{8} \mathrm{H}_{6} \mathrm{O}_{8} \cdot 2 \mathrm{H}_{2} \mathrm{O}>\mathrm{Cd}_{2} \mathrm{C}_{8} \mathrm{H}_{6} \mathrm{O}_{8} \cdot 2 \mathrm{H}_{2} \mathrm{O}>$ $\mathrm{Mn}_{2} \mathrm{C}_{8} \mathrm{H}_{6} \mathrm{O}_{8} \cdot 2 \mathrm{H}_{2} \mathrm{O}>\mathrm{Ni}_{2} \mathrm{C}_{8} \mathrm{H}_{6} \mathrm{O}_{8} \cdot 2 \mathrm{H}_{2} \mathrm{O}>$ $\mathrm{Zn}_{2} \mathrm{C}_{8} \mathrm{H}_{6} \mathrm{O}_{8} \cdot 2 \mathrm{H}_{2} \mathrm{O}>\mathrm{Zn}_{2} \mathrm{C}_{8} \mathrm{H}_{6} \mathrm{O}_{8} \cdot 2 \mathrm{H}_{2} \mathrm{O}>$ $\mathrm{Cu}_{2} \mathrm{C}_{8} \mathrm{H}_{6} \mathrm{O}_{8} \cdot 2 \mathrm{H}_{2} \mathrm{O}$

\section{Concluding remarks}

In the experimental process, 1,2,3,4-butane tetracarboxylic acid tetrasodium salt $\left(\mathrm{Na}_{4} \mathrm{C}_{8} \mathrm{H}_{6} \mathrm{O}_{8}\right)$ was prepared by reaction with excess metal salts. The composition and structure of the prepared metal complexes were characterized by infrared spectroscopy, 
thermogravimetric analysis and elemental analysis. At the same time, the thermal stability of the complex was studied by thermogravimetric analysis, and the order of thermal stability was obtained as follows: $\mathrm{Co}_{2} \mathrm{C}_{8} \mathrm{H}_{6} \mathrm{O}_{8} \cdot 2 \mathrm{H}_{2} \mathrm{O}>\mathrm{Cd}_{2} \mathrm{C}_{8} \mathrm{H}_{6} \mathrm{O}_{8} \quad \cdot 2 \mathrm{H}_{2} \mathrm{O}>$ $\mathrm{Mn}_{2} \mathrm{C}_{8} \mathrm{H}_{6} \mathrm{O}_{8} \cdot 2 \mathrm{H}_{2} \mathrm{O}>\mathrm{Ni}_{2} \mathrm{C}_{8} \mathrm{H}_{6} \mathrm{O}_{8} \cdot 2 \mathrm{H}_{2} \mathrm{O}>$ $\mathrm{Zn}_{2} \mathrm{C}_{8} \mathrm{H}_{6} \mathrm{O}_{8} \cdot 2 \mathrm{H}_{2} \mathrm{O}>\mathrm{Zn}_{2} \mathrm{C}_{8} \mathrm{H}_{6} \mathrm{O}_{8} \cdot 2 \mathrm{H}_{2} \mathrm{O}>$ $\mathrm{Cu}_{2} \mathrm{C}_{8} \mathrm{H}_{6} \mathrm{O}_{8} \cdot 2 \mathrm{H}_{2} \mathrm{O}$

\section{References}

1. Xiao Huifang, Yan Kelu, Ji Berlin. Application of sugar additives in wrinkle-resistant finishing of cotton fabric with 1,2,3,4-butane tetracarboxylic acid [J]. Journal of Textiles, 2018 (7): 89-94.

2. Preparation and characterization of transition metal complexes of Zhang Cheng, Zhang Lianhui, Jiang Heng, Gonghong and Wang Rui.1, 2, 3, 4-butane tetracarboxylic acid [J]. Chemical reagent, 2005 (02): 75-78.

3. Wang Licheng, Wang Jingyue, Yang Yuanyuan. Preparation of 1,2,3,4-butane tetracarboxylic acid [J/OL] by ozonation. Yunnan Chemical Industry: 1-5
[2018-10-13].

4. Xingjun Gao, Huan Zhang, Xianhong Wen, Bin Liu, Shouwen Jin, Daqi Wang. Structure of seven organic salts assembled from 2,6-diaminopyridine with monocarboxylic acids, dicarboxylic acids, and tetracarboxylic acids [J]. Journal of Molecular Structure, 2015, 1093.

5. Guo Zhengnan, Liu E, Wei Xi, Tang Qun, Li Huanlin. Synthesis, characterization and properties of metal-organic frameworks using 1,2,4,5-benzotetracarboxylic acid or 1,2,3,4-butane tetracarboxylic acid as ligands $[\mathrm{J}]$. Journal of Inorganic Chemistry, 2016,32(01): 9-17.

6. Hao Wenbo, Yan Kelu, Chen Yongbang, Huang Jinxu. Antimicrobial/wrinkle-resistant composite finishing of cotton fabric with chitosan and butane tetracarboxylic acid [J]. Journal of Textiles, 2016, 37 (06): 95-100.

7. Wang Li, Jia Ru, Zhou Yonghua. Study on the reaction process of butane tetracarboxylic acid [J]. Acetaldehyde acetic acid chemical industry, 2016 (07): 14-15+22. 